\title{
EVALUATION OF REGIONAL PEDO- TRANSFER FUNCTIONS BASED ON THE BP NEURAL NETWORKS
}

\author{
Zhongyi Qu ${ }^{1, *}$, Guanhua Huang ${ }^{2}$, Jingyu Yang ${ }^{3}$ \\ ${ }^{1}$ College of Hydraulic and Civil Engineering, Inner Mongolia Agricultural University, \\ Huhhot, China, 010018; \\ ${ }^{2}$ Chinese-Israeli International Center for Research and Training in Agriculture, China \\ Agricultural University, Beijing 100083, P. R. China \\ 3 Institute of City Planning and Design, China Architecture Institute, Beijing, China, 100007 \\ * Corresponding author, Address:, College of Hydraulic and Civil Engineering, Inner \\ Mongolia Agricultural University y, 306 Zhaowuda Road, Huhhot, 010018, P. R. China, \\ Tel:+86-471-4300181, Fax:+86-471-4300249, Email:qzy682000@yaohoo.com.cn
}

Abstract: The unsaturated soil hydraulic properties, including soil water retention curve and hydraulic conductivity, are the crucial input parameters for simulating soil water and solute transport through the unsaturated zone at regional scales, and are expensive to measure. These properties are frequently predicted with pedotransfer functions (PTFs) using the routinely measured soil properties. 110 soil samples at 22 soil profiles from Jiefangzha Irrigation Scheme in the Hetao Irrigation District of Inner Mongolia, China were collected for the analysis of soil properties i.e. soil bulk density, soil texture, particle size distribution, organic content, and soil water retention curve (SWRC). The Brooks-Corey (BC) model and van Genuchten (VG) model were used to fit the measured SWRC data for each soil sample by using the RETC software. Pedo-transfer functions (PTFS), which describes relationship between the basic soil properties and the parameters of the $\mathrm{BC}$ and VG models, were then established with the artificial neural networks (ANN) model. It is found that the ANN model has better effect on the clay loam, loamy clay, loam soil and silty clay to simulate BC model. However, it has better effect on the loam soil, loamy clay and sandy clay to simulate VG model. So, we can draw the conclusion that the ANN model can conveniently establish PTFS between soil basic feature parameters and SWRC model and has reasonable precision. This will be a good method to estimate soil water characteristic curve model and soil hydraulic parameter in the regional soil water and salt movement simulation and water resources evaluation.

Please use the following format when citing this chapter:

Qu, Z., Huang, G. and Yang, J., 2009, in IFIP International Federation for Information Processing, Volume 294, Computer and Computing Technologies in Agriculture II, Volume 2, eds. D. Li, Z. Chunjiang, (Boston: Springer), pp. 1189-1199. 
Keywords: Hetao Irrigation District, BP model, pedo-transfer functions, soil water retention curve, soil basic property

\section{INTRODUCTION}

Soil hydraulic properties, including soil water retention curve (SWRC) and hydraulic conductivity, are the crucial parameters for simulating soil water and solute transport through saturated and unsaturated zone. Many empirical models were developed to describe the soil hydraulic properties, among them both the van Genuchten (VG) model (van Genuchten, 1980) and Brooks-Corey (BC) (Brooks and Corey, 1974) model are widely used in the simulation of water and solute transport. However, for large-scale problems, when the temporal and spatial variability of the region is considered, the required measurements of soil hydraulic properties are tremendous, time-consuming, and very expensive. The pedo-transfer functions (PTFs) are the promising tool to estimate the soil hydraulic properties with more easily measured or basic soil properties in the attribute database of a digital soil survey map, in which soil hydraulic properties are not always available. The PTFs for soil hydraulic properties are those functions, with which the parameters in VG and /or BC model are expressed as the linear or nonlinear empirical functions of different land characteristics and soil properties, i.e. soil texture (including sand, silt and clay contents), bulk density and organic mater content (Pachepsky et al., 1996; Tamari et al., 1996; Schaap and Leij, 1998; Minasny et al., 1999; Schaap et al., 2001).

The PTFs were firstly described by Bouma and van Lanen (1987), .a recent approach for fitting PTFs is to use artificial neural networks (ANN) (Pachepsky et al., 1996; Schaap et al., 1998). Tamari and Wosten (1999) gave a review on the ANN and its application on predicting soil hydraulic properties. Most researchers have found that the ANN performs better than multi regression (Schaap et al., 1998, Koekkoek and Booltink, 1999). More recently, based on the ANN, Budiman et al. (2002) and Nemes et al. (2003) developed computer codes for the PTFs. An advantage of using the ANN based approach is that there is needed to assume a prior relationship. Minasny et al.(1999) found that the ANN based approach performs as well as the extended nonliner regression. Because the PTFs are site specific, the PTFs developed in one region are not always applicable in other regions with acceptable accuracy (Tietje and Tapkenhinrichs, 1993; Kern, 1995; Tietje and Hennings, 1996; Cornelis et al., 2001; Wagner et al., 2001; Nemes et al., 2003). Therefore, it is necessary to develop the PTFs for any specific study areas.

The objective of this study is to develop the PTFs for estimating the parameters of the $\mathrm{VG}$ and $\mathrm{BC}$ models with the use of $\mathrm{ANN}$, based on the 
datasets collected in Jiefangzha Irrigation Scheme (see the Fig.1) of Hetao Irrigation District in Inner Mongolia, China. And the PTFs will be used to develop the digital soil map for the spatial distribution of SWRC in the study area.

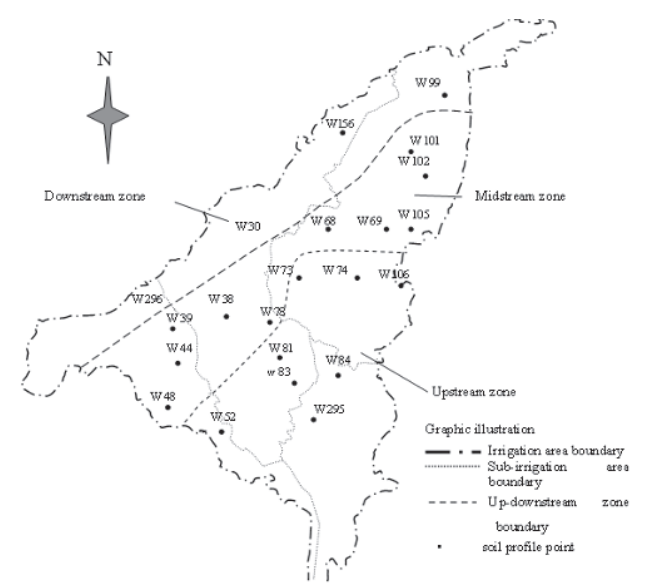

Fig. 1: The sampling sites of 22 soil profiles in Jiefangzha Irrigation Scheme.

\section{MATERIALS AND METHODS}

\subsection{Soil sampling}

The soil samples were collected from Jiefangzha Irrigation Scheme in the Hetao Irrigation District of Inner Mongolia, northwest of China(see the Fig.1). The total area of Jiefangzha Irrigation Scheme is $2.16 \times 10^{5} \mathrm{hm}^{2} .22$ points were selected for monitoring soil water and salt content in this area. Undisturbed soil samples were collected by using two kinds of soil samplers from soil layers $0-10 \mathrm{~cm}, 10-20 \mathrm{~cm}, 20-40 \mathrm{~cm}, 40-70 \mathrm{~cm}$, and $70-100 \mathrm{~cm}$ along soil profiles at each monitoring point. The first kind of soil sampler has diameter $50.46 \mathrm{~mm}$ and height $35 \mathrm{~mm}$, while the second kind of soil sampler has diameter $50.46 \mathrm{~mm}$ and height $50 \mathrm{~mm}$. Soil samples with the first kind of soil sampler are collected for each layer, and they were used to determine the bulk density and porosity. While soil samples with the second kind of soil sampler are collected for each layer, and they were used to determine the SWRC by using a pressure apparatus (Soilmositure, USASEC) at the different suction pressures $0,100,200,300,400,500,600,900$, $1100,2200,3300,4400,5500,7700,9900,12400,14800 \mathrm{~cm} .$. At the same time, $500 \mathrm{~g}$ disturbed soil samples each at the same layer as that of the undisturbed sample for all profiles. The disturbed soil samples were used to determine soil particle size distribution by using the sieve method and 
gravimeter. The organic matter content was determined by the WalkeyBlack method.

\subsection{VG and BC models}

The VG model for SWRC can be expressed (van Genuchten, 1980):

$$
S_{e}=\frac{\theta-\theta_{r}}{\theta_{s}-\theta_{r}}=\left[1+(\alpha h)^{n}\right]^{-m}
$$

where $S_{\mathrm{e}}$ is the degree of soil saturation; $\theta$ denotes the volumetric soil water content $\left(\mathrm{cm}^{3} . \mathrm{cm}^{-3}\right), \theta_{r}$ and $\theta_{\mathrm{s}}$ are the soil residual and saturated volumetric water contents $\left(\mathrm{cm}^{3} \mathrm{~cm}^{-3}\right)$, respectively, $h$ is the soil water pressure head $(\mathrm{cm}) ; \alpha$ in $\mathrm{cm}^{-1}, n$ and $m$ are parameters defining the SWRC shape, and $m=1-1 / n$.

The BC model for SWRC can be expressed (Brook and Corey, 1974):

$$
S_{e}= \begin{cases}\left(\alpha_{1} h\right)^{-\lambda} & \left(\alpha_{1} h>1\right) \\ 1 & \left(\alpha_{1} h \leq 1\right)\end{cases}
$$

Where $\alpha_{1}$ is parameter reflecting the value of air entry suction; $\lambda$ is the soil pore-size distribution index.

The model parameters $\theta_{r}, \theta_{s}, \alpha, \alpha_{1}, n, m$ and $\lambda$ were obtained by fitting the two functions to the measured soil water retention data with the nonlinear leastsquares optimization program RETC (van Genuchten et al., 1991).

\subsection{Pedo-transfer functions of neural networks}

Neural network model is quite powerful and according to Gershenfeld (1999) with on hidden layer that has enough hidden units, it can describe any continuous function. Conventionally, parametric PTFs train the network to fit the estimated van Genuchten parameters. But there are some problems (Budiman Minasny and McBratney, 2002). Based on the ANN theory (Gershenfeld, 1999), we proposed a new objective function for neural network training, which can predict the VG and $\mathrm{BC}$ model parameters with minimizing the difference between the measured water contents and the predicted values. The detail procedure can be seen in Fig.2. The steps are as follows:

1). fit the individual water-retention curve to van Gentuchten function and Brooks-Corey function and estimate the parameters $\theta_{r}, \theta_{s}, \alpha, \alpha_{1}, n$ and $\lambda$.

2).Train the neural network to predict the parameter vector $\mathbf{p}=\left[\theta_{\mathrm{r}}\right.$, $\left.\theta_{\mathrm{s}}, \alpha, n\right]$ from basic soil properties by minimizing objective function.

The above steps are usually used for parametric PTFs. It is a neural network with an objective function that matches the parameters. The proposed method continues with fine-tuning steps described below:

$3)$. Use the trained weights as an initial guess for the second training, which fine tunes the estimates. 
4). For each soil sample, predict the hydraulic parameters with the trained weights, and calculate the water content using the van Genuchten equation and Brooks-Corey equation at each of the measured potentials.

5). Adjust the weights and error $\mathbf{U}$, to minimize the difference between the predicted and measured water content with the optimization routine. A neural network with an objective function can match the measured or observed values.

The neural network based PTFs can predict the model parameters $\theta_{r}$, $\theta_{s}, \alpha, \alpha_{1}, n, m$ and $\lambda$ with basic soil properties as their inputs. Four kinds of inputs were considered: (1) when particle size distribution is only available, the inputs are sand $(>0.05 \mathrm{~mm})$, silt $(0.05-0.002 \mathrm{~mm})$ and clay $(<0.002 \mathrm{~mm})$ contents;(2) the inputs are particle size distribution and soil bulk density; (3) the inputs are particle size distribution and soil organic matter content; (4) the inputs are particle size distribution, soil bulk density and soil organic matter content. The data was randomly divided into a calibration set with 80 samples and a validation set with 30 samples. Because $\alpha$ and $n$ are $\log$ normally distributed, the outputs of prediction are $\theta_{s}, \theta_{r}, \ln (\alpha), \ln (n)$. The network consists of one hidden layer with sigmoid action function in the hidden layer and linear function in the output. The parameters of ANN model were determined by trial and error method. The BP network was performed with the Neural Network Toolbox in MATLAB program ver.7.0 .

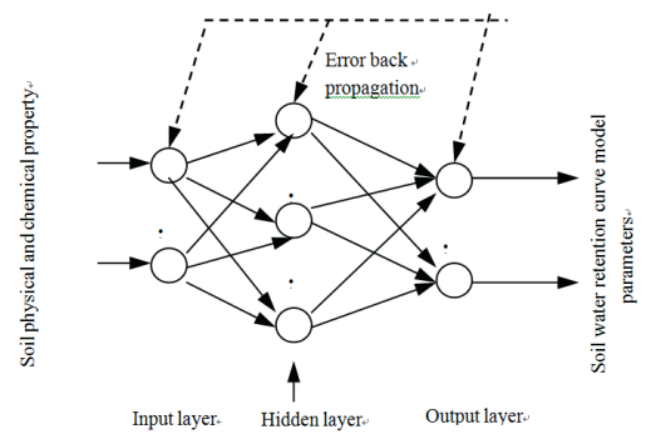

Fig. 2 structure of a neural network predicting the Van Genuchten and Brooks-Corey model parameters

\section{RESULTS AND DISCUSSION}

\subsection{Physical and chemical properties}

The physical and chemical properties of 110 soil samples at 22 profiles were shown in Table1. Loamy soils account for $68.2 \%$ of the total soil 
samples, clay soils accounts for $30 \%$ of the total soil samples, where sandy soil only accounts for less than $3 \%$ of the total soil samples. The spatial distributions of soil texture in the study area are sand clay loam, loam and clay loam in the upstream zone (southern part). Most soil textures are clay loam in the midstream zone (middle part), while loamy clay is the main soil texture in the northern part. In the soil horizon of $0 \sim 40 \mathrm{~cm}$, sandy clay loam accounts for $70 \%$ of the soil textures in the upstream zone (southern part), clay loam accounts for $65 \%$ of the soil textures in the midstream zone (middle part), while loamy clay land clay loam are the major soil textures in the downstream zone (northern part). The statistics results of total 110 soil samples see the table 1. It is founded that the organic matter content of sandy loam, loam and clay loam are relative high. This can indicate that the soil texture has closely relation with physical and chemical property of soil.

Table 1 Physical and chemical properties and their statistical results of soil samples

\begin{tabular}{|c|c|c|c|c|c|c|c|}
\hline Soil texture & $\begin{array}{l}\text { Sample } \\
\text { number }\end{array}$ & $\begin{array}{l}\text { Statistical } \\
\text { properties }\end{array}$ & $\begin{array}{c}\text { Sand } \\
(\%)\end{array}$ & $\begin{array}{l}\text { Silt } \\
(\%)\end{array}$ & $\begin{array}{l}\text { Clay } \\
(\%)\end{array}$ & $\begin{array}{c}\text { Bulk density } \\
\left(\mathrm{g} / \mathrm{cm}^{3}\right)\end{array}$ & $\begin{array}{c}\text { Organic matter content } \\
(\mathrm{g} / \mathrm{kg})\end{array}$ \\
\hline \multirow{3}{*}{ Loamy sand } & \multirow{3}{*}{3} & mean & 88.96 & 6.68 & 4.36 & 1.436 & 9.06 \\
\hline & & median & 86.95 & 8.26 & 4.16 & 1.444 & 2.091 \\
\hline & & S.D & 2.12 & 2.02 & 0.22 & 0.003 & 1.014 \\
\hline \multirow{3}{*}{ Sandy loam } & \multirow{3}{*}{13} & mean & 68.64 & 23.36 & 8.00 & 1.446 & 7.488 \\
\hline & & median & 69.21 & 23.18 & 7.01 & 1.441 & 4.927 \\
\hline & & S.D & 2.98 & 2.86 & 0.86 & 0.007 & 0.687 \\
\hline \multirow{3}{*}{$\begin{array}{l}\text { Sand clay } \\
\text { loam }\end{array}$} & \multirow{3}{*}{1} & mean & 60.46 & 21.03 & 18.51 & 1.474 & 14.420 \\
\hline & & median & - & - & - & - & - \\
\hline & & S.D & - & - & - & - & - \\
\hline \multirow{3}{*}{ Loam } & \multirow{3}{*}{10} & mean & 49.84 & 38.20 & 11.96 & 1.438 & 8.948 \\
\hline & & median & 50.77 & 36.54 & 12.56 & 1.449 & 10.126 \\
\hline & & S.D & 1.26 & 1.46 & 0.61 & 0.009 & 0.661 \\
\hline \multirow{3}{*}{ Silt loam } & \multirow{3}{*}{7} & mean & 35.78 & 55.17 & 9.042 & 1.437 & 4.654 \\
\hline & & median & 36.95 & 52.91 & 9.50 & 1.418 & 0.794 \\
\hline & & S.D & 2.19 & 1.80 & 1.32 & 0.006 & 4.301 \\
\hline \multirow{3}{*}{ Silt clay loam } & \multirow{3}{*}{18} & mean & 29.38 & 50.36 & 20.26 & 1.446 & 8.671 \\
\hline & & median & 30.23 & 48.77 & 20.24 & 1.429 & 4.370 \\
\hline & & S.D & 1.25 & 1.37 & 0.67 & 0.010 & 0.512 \\
\hline \multirow{3}{*}{ Clay loam } & \multirow{3}{*}{26} & mean & 42.88 & 37.43 & 19.70 & 1.493 & 9.047 \\
\hline & & median & 41.99 & 36.93 & 19.54 & 1.486 & 4.327 \\
\hline & & S.D & 1.14 & 1.02 & 0.51 & 0.012 & 0.441 \\
\hline \multirow{3}{*}{ Loam clay } & \multirow{3}{*}{19} & mean & 27.00 & 41.10 & 31.90 & 1.405 & 12.773 \\
\hline & & median & 27.74 & 41.45 & 31.56 & 1.401 & 9.468 \\
\hline & & S.D & 1.278 & 0.78 & 0.95 & 0.008 & 0.564 \\
\hline \multirow{3}{*}{ Silt clay } & \multirow{3}{*}{13} & mean & 15.95 & 51.62 & 32.43 & 1.454 & 8.144 \\
\hline & & median & 14.14 & 51.22 & 32.35 & 1.432 & 3.819 \\
\hline & & S.D & 1.61 & 1.26 & 1.17 & 0.021 & 0.616 \\
\hline
\end{tabular}

S.D : Standard deviation 


\subsection{The fit and establishment of soil water retention curve (SWRC) model}

By fitting the VG and $\mathrm{BC}$ model to the measured data for each soil sample, we obtained the model parameters as shown in Table 2 and Table 3. According to the fitted results we found that the model parameters of VG model and BC model soil property have significant influence on parameter of model. For example, the $n$ of VG model will decrease with the decrease of organic matter content (see the table 1). At the same time, the soil clay particle content has good relations with $n, \alpha$ of VG model.

According to the fitting results, it is found that the two kinds of models have good effects. The model parameter of 9 kinds soil texture was calculated their average (see the table 2 and table 3). The maximum error of measured value and fitted value is less than 5\%. Furthermore, the Van Genuchten is better than Brooks-Corey model.

Table 2 The fitted parameters for van Genuchten model by using the RETC program

\begin{tabular}{|c|c|c|c|c|c|c|c|c|}
\hline $\begin{array}{l}\text { Soil } \\
\text { texture }\end{array}$ & $\begin{array}{c}\text { Sample } \\
\text { number }\end{array}$ & $\begin{array}{l}\text { Statistical } \\
\text { properties }\end{array}$ & $\begin{array}{c}\theta_{r} \\
\left(\mathrm{~cm}^{3} \mathbf{c m}^{-3}\right)\end{array}$ & $\begin{array}{c}\theta_{s} \\
\left(\mathrm{~cm}^{3} \mathrm{~cm}^{-3}\right)\end{array}$ & $\begin{array}{c}\alpha \\
\left(\mathrm{cm}^{-1}\right)\end{array}$ & $n$ & $m=1-1 / n$ & $\begin{array}{l}\text { Determination } \\
\text { coefficient }\left(R^{2}\right)\end{array}$ \\
\hline \multirow{4}{*}{$\begin{array}{l}\text { Loamy } \\
\text { sand }\end{array}$} & \multirow{4}{*}{3} & Mean & 0 & 0.512 & 0.009 & 1.536 & 0.345 & 0.98 \\
\hline & & Maximum & 0 & 0.530 & 0.012 & 1.690 & 0.408 & 0.99 \\
\hline & & Minimum & 0 & 0.489 & 0.008 & 1.408 & 0.290 & 0.97 \\
\hline & & S.D. & 0 & 0.021 & 0.002 & 0.142 & 0.059 & \\
\hline \multirow{4}{*}{$\begin{array}{l}\text { Sandy } \\
\text { loam }\end{array}$} & \multirow{4}{*}{13} & Mean & 0.111 & 0.482 & 0.013 & 1.373 & 0.251 & 0.98 \\
\hline & & Maximum & 0.175 & 0.543 & 0.046 & 2.062 & 0.515 & 0.99 \\
\hline & & Minimum & 0.171 & 0.442 & 0.002 & 1.096 & 0.088 & 0.98 \\
\hline & & S.D. & 0.037 & 0.030 & 0.014 & 0.263 & 0.122 & \\
\hline \multirow[b]{2}{*}{$\begin{array}{l}\text { Sand } \\
\text { clay } \\
\text { loam }\end{array}$} & \multirow[b]{2}{*}{1} & Mean & 0.135 & 0.450 & 0.034 & 1.150 & 0.131 & 0.97 \\
\hline & & $\begin{array}{l}\text { Maximum } \\
\text { Minimum } \\
\text { S.D. }\end{array}$ & & & & & & \\
\hline \multirow{4}{*}{ loam } & \multirow{4}{*}{10} & Mean & 0.088 & 0.500 & 0.028 & 1.287 & 0.194 & 0.98 \\
\hline & & Maximum & 0.139 & 0.619 & 0.053 & 2.060 & 0.514 & 0.99 \\
\hline & & Minimum & 0.038 & 0.430 & 0.002 & 1.056 & 0.053 & 0.98 \\
\hline & & S.D. & 0.071 & 0.056 & 0.016 & 0.304 & 0.140 & \\
\hline \multirow{4}{*}{$\begin{array}{l}\text { Silt } \\
\text { loam }\end{array}$} & \multirow{4}{*}{7} & Mean & 0.03 & 0.53 & 0.01 & 1.33 & 0.23 & 0.99 \\
\hline & & Maximum & 0.126 & 0.56 & 0.02 & 1.78 & 0.44 & 0.99 \\
\hline & & Minimum & 0 & 0.47 & 0 & 1.10 & 0.09 & 0.98 \\
\hline & & S.D. & 0.05 & 0.04 & 0.01 & 0.24 & 0.12 & \\
\hline \multirow{4}{*}{$\begin{array}{l}\text { Silt } \\
\text { clay } \\
\text { loam }\end{array}$} & \multirow{4}{*}{18} & Mean & 0.149 & 0.508 & 0.048 & 1.151 & 0.128 & 0.98 \\
\hline & & Maximum & 0.226 & 0.56 & 0.165 & 1.352 & 0.260 & 0.99 \\
\hline & & Minimum & 0.069 & 0.443 & 0.001 & 1.07 & 0.065 & 0.97 \\
\hline & & S.D. & 0.065 & 0.037 & 0.046 & 0.079 & 0.055 & \\
\hline \multirow{4}{*}{$\begin{array}{l}\text { Clay } \\
\text { loam }\end{array}$} & \multirow{4}{*}{26} & Mean & 0.095 & 0.485 & 0.025 & 1.230 & 0.177 & 0.98 \\
\hline & & Maximum & 0.137 & 0.565 & 0.083 & 1.674 & 0.403 & 0.99 \\
\hline & & Minimum & 0.026 & 0.427 & 0.002 & 1.079 & 0.074 & 0.97 \\
\hline & & S.D. & 0.060 & 0.033 & 0.021 & 0.149 & 0.087 & \\
\hline \multirow{4}{*}{$\begin{array}{l}\text { Loam } \\
\text { clay }\end{array}$} & \multirow{4}{*}{19} & Mean & 0.167 & 0.501 & 0.098 & 1.179 & 0.139 & 0.98 \\
\hline & & Maximum & 0.222 & 0.617 & 1.098 & 1.671 & 0.401 & 0.99 \\
\hline & & Minimum & 0.050 & 0.429 & 0.003 & 1.059 & 0.056 & 0.97 \\
\hline & & S.D. & 0.073 & 0.044 & 0.247 & 0.159 & 0.095 & \\
\hline \multirow{4}{*}{$\begin{array}{l}\text { Silt } \\
\text { clay }\end{array}$} & \multirow{4}{*}{13} & Mean & 0.202 & 0.542 & 0.072 & 1.129 & 0.112 & 0.98 \\
\hline & & Maximum & 0.294 & 0.604 & 0.179 & 1.258 & 0.205 & 0.99 \\
\hline & & Minimum & 0.118 & 0.454 & 0.003 & 1.056 & 0.053 & 0.97 \\
\hline & & S.D. & 0.071 & 0.049 & 0.066 & 0.064 & 0.048 & \\
\hline
\end{tabular}


Table 3 The fitted parameters for Brook and Corey model by using the RETC program

\begin{tabular}{|c|c|c|c|c|c|c|c|}
\hline $\begin{array}{l}\text { Soil } \\
\text { texture }\end{array}$ & $\begin{array}{l}\text { Sample } \\
\text { number }\end{array}$ & $\begin{array}{l}\text { Statistical } \\
\text { properties }\end{array}$ & $\begin{array}{c}\theta_{r} \\
\left(\mathrm{~cm}^{3} \mathrm{~cm}^{-3}\right)\end{array}$ & $\begin{array}{c}\theta_{s} \\
\left(\mathrm{~cm}^{3} \mathrm{~cm}^{-3}\right)\end{array}$ & $\begin{array}{c}\alpha_{1} \\
\left(\mathrm{~cm}^{-1}\right)\end{array}$ & $\lambda$ & $\begin{array}{l}\text { Determination } \\
\text { Coefficient }\left(R^{2}\right)\end{array}$ \\
\hline \multirow{4}{*}{$\begin{array}{l}\text { Loamy } \\
\text { sand }\end{array}$} & \multirow{4}{*}{3} & Mean & 0 & 0.464 & 0.023 & 0.268 & 0.97 \\
\hline & & Maximum & 0 & 0.480 & 0.048 & 0.433 & 0.99 \\
\hline & & Minimum & 0 & 0.455 & 0.010 & 0.013 & 0.96 \\
\hline & & S.D. & 0 & 0.031 & 0.021 & 0.22 & \\
\hline \multirow{4}{*}{$\begin{array}{l}\text { Sandy } \\
\text { loam }\end{array}$} & \multirow{4}{*}{13} & Mean & 0.072 & 0.469 & 0.018 & 0.234 & 0.97 \\
\hline & & Maximum & 0.120 & 0.510 & 0.065 & 0.409 & 0.99 \\
\hline & & Minimum & 0.011 & 0.433 & 0.004 & 0.080 & 0.96 \\
\hline & & S.D. & 0.047 & 0.025 & 0.017 & 0.094 & \\
\hline \multirow{3}{*}{$\begin{array}{l}\text { Sand clay } \\
\text { loam }\end{array}$} & \multirow{3}{*}{1} & Mean & 0.095 & 0.450 & 0.045 & 0.119 & 0.98 \\
\hline & & Maximum & & & & & \\
\hline & & $\begin{array}{l}\text { Minimum } \\
\text { S.D. }\end{array}$ & & & & & \\
\hline \multirow{4}{*}{ loam } & \multirow{4}{*}{10} & Mean & 0.087 & 0.486 & 0.033 & 0.236 & 0.97 \\
\hline & & Maximum & 0.117 & 0.621 & 0.058 & 0.622 & 0.99 \\
\hline & & Minimum & 0.020 & 0.413 & 0.004 & 0.055 & 0.96 \\
\hline & & S.D. & 0.045 & 0.057 & 0.019 & 0.164 & \\
\hline \multirow{4}{*}{ Silt loam } & \multirow{4}{*}{7} & Mean & 0.02 & 0.51 & 0.01 & 0.24 & 0.97 \\
\hline & & Maximum & 0.07 & 0.55 & 0.03 & 0.55 & 0.97 \\
\hline & & Minimum & 0 & 0.46 & 0.00 & 0.09 & 0.96 \\
\hline & & S.D. & 0.03 & 0.04 & 0.01 & 0.16 & \\
\hline \multirow{4}{*}{$\begin{array}{l}\text { Silt clay } \\
\text { loam }\end{array}$} & \multirow{4}{*}{18} & Mean & 0.145 & 0.501 & 0.048 & 0.141 & 0.96 \\
\hline & & Maximum & 0.209 & 0.56 & 0.153 & 0.254 & 0.97 \\
\hline & & Minimum & 0.110 & 0.43 & 0.004 & 0.066 & 0.94 \\
\hline & & S.D. & 0.039 & 0.039 & 0.038 & 0.059 & \\
\hline \multirow{4}{*}{ Clay loam } & \multirow{4}{*}{26} & Mean & 0.114 & 0.466 & 0.022 & 0.239 & 0.97 \\
\hline & & Maximum & 0.185 & 0.540 & 0.087 & 0.570 & 0.98 \\
\hline & & Minimum & 0.023 & 0.430 & 0.004 & 0.073 & 0.95 \\
\hline & & S.D. & 0.047 & 0.028 & 0.021 & 0.125 & \\
\hline \multirow{4}{*}{ Loam clay } & \multirow{4}{*}{19} & Mean & 0.160 & 0.495 & 0.044 & 0.158 & 0.98 \\
\hline & & Maximum & 0.260 & 0.610 & 0.171 & 0.577 & 0.99 \\
\hline & & Minimum & 0.019 & 0.430 & 0.004 & 0.061 & 0.96 \\
\hline & & S.D. & 0.085 & 0.043 & 0.044 & 0.127 & \\
\hline \multirow{4}{*}{ Silt clay } & \multirow{4}{*}{13} & Mean & 0.178 & 0.537 & 0.090 & 0.108 & 0.96 \\
\hline & & Maximum & 0.248 & 0.600 & 0.200 & 0.211 & 0.99 \\
\hline & & Minimum & 0.063 & 0.453 & 0.006 & 0.055 & 0.94 \\
\hline & & S.D. & 0.081 & 0.047 & 0.073 & 0.051 & \\
\hline
\end{tabular}

\subsection{Pedo-transfer functions based on ANN model}

The training of BP model was performed by using the randomly selected 80 soil samples, and the parameters of the two models were estimated according to the basic soil property data. And then the established ANN PTFs were tested with another 30 sample data. The tested results were shown in Tables 4 and 5. It can be found that the average relative error (ARE) decreases gradually with inputs factors increase. Therefore, it is better to estimate the parameters of SWRC by using soil bulk density, particle size distribution and soil organic matter contents.

From the comparison of two kinds of models, VG model is better than BC model. From the table 4 and table 5 we can see that, the ANN model has good prediction ability.

As shown in table 4 and table 5 , it can be found that the predicted values and approach the measured values well with the inputs of particle size 
distribution + soil organic matter content + soil bulk density. The four parameters $\mathrm{R} 2$ are greater than 0.5 . Through the comparison of the soil water retention curve (SWRC) model fitted by BC and VG with that fitted by basic soil properties and measured SWRC, it can be found that the different SWRC model has different effect for the different soil texture. The BC model has better effect for the clay loam, loamy clay, loam and silty clay. However, the VG model has better effect for the loam, loamy clay and sandy clay.

Table 4 Error analysis of predicted results for BC model parameters

\begin{tabular}{|c|c|c|c|}
\hline Inputs & Output & Average absolute error & Average relative error(\%) \\
\hline \multirow{4}{*}{ Particle size distribution } & $\theta_{r}$ & 0.0465 & 26.22 \\
\hline & $\theta_{s}$ & 0.0111 & 6.27 \\
\hline & $\operatorname{Ln}\left(\alpha_{1}\right)$ & 0.0474 & 26.72 \\
\hline & $\operatorname{Ln}(\lambda)$ & 0.3671 & 6.99 \\
\hline \multirow{4}{*}{$\begin{array}{l}\text { Particle size distribution }+ \text { soil } \\
\text { organic matter content }\end{array}$} & $\theta_{r}$ & -0.0031 & 0.62 \\
\hline & $\theta_{s}$ & -0.0111 & 2.21 \\
\hline & $\operatorname{Ln}\left(\alpha_{1}\right)$ & 0.0022 & 0.44 \\
\hline & $\operatorname{Ln}(\lambda)$ & -0.0144 & 2.84 \\
\hline \multirow{4}{*}{$\begin{array}{l}\text { Particle size distribution }+ \text { soil } \\
\text { bulk density }\end{array}$} & $\theta_{r}$ & -0.1738 & 4.33 \\
\hline & $\theta_{s}$ & -0.1679 & 4.19 \\
\hline & $\operatorname{Ln}\left(\alpha_{1}\right)$ & -0.0233 & 4.58 \\
\hline & $\operatorname{Ln}(\lambda)$ & -0.3962 & 9.88 \\
\hline \multirow{4}{*}{$\begin{array}{l}\text { Particle size distribution }+ \text { soil } \\
\text { organic matter content }+ \text { soil } \\
\text { bulk density }\end{array}$} & $\theta_{r}$ & -0.0020 & 0.22 \\
\hline & $\theta_{s}$ & -0.1578 & 4.37 \\
\hline & $\operatorname{Ln}\left(\alpha_{1}\right)$ & -0.0480 & 3.29 \\
\hline & $\operatorname{Ln}(\lambda)$ & -0.0230 & 2.54 \\
\hline \multicolumn{4}{|c|}{ Table 5 Error analysis of predicted results for VG model parameters } \\
\hline Inputs & Output & Average absolute error & Average relative error $(\%)$ \\
\hline \multirow{4}{*}{ particle size distribution } & $\theta_{r}$ & 0.0420 & 23.70 \\
\hline & $\theta_{s}$ & 0.0211 & 11.89 \\
\hline & $\operatorname{Ln}(\alpha)$ & 0.0388 & 21.85 \\
\hline & $\operatorname{Ln}(n)$ & 0.0150 & 8.44 \\
\hline \multirow{4}{*}{$\begin{array}{l}\text { particle size distribution }+ \\
\text { soil organic matter content }\end{array}$} & $\theta_{r}$ & -0.0050 & 0.98 \\
\hline & $\theta_{s}$ & 0.0039 & 0.76 \\
\hline & $\operatorname{Ln}(\alpha)$ & -0.0077 & 1.52 \\
\hline & $\operatorname{Ln}(n)$ & -0.0097 & 1.92 \\
\hline \multirow{4}{*}{$\begin{array}{l}\text { particle size distribution }+ \text { soil } \\
\text { bulk density }\end{array}$} & $\theta_{r}$ & -0.3217 & 7.10 \\
\hline & $\theta_{s}$ & -0.1848 & 4.08 \\
\hline & $\operatorname{Ln}(\alpha)$ & 0.0253 & 0.55 \\
\hline & $\operatorname{Ln}(n)$ & -0.3788 & 8.36 \\
\hline \multirow{4}{*}{$\begin{array}{l}\text { particle size distribution }+ \text { soil } \\
\text { organic matter content }+ \\
\text { soil bulk density }\end{array}$} & $\theta_{r}$ & 0.0247 & 6.09 \\
\hline & $\theta_{s}$ & 0.0029 & 0.71 \\
\hline & $\operatorname{Ln}(\alpha)$ & 0.0081 & 1.99 \\
\hline & $\operatorname{Ln}(n)$ & 0.0139 & 3.41 \\
\hline
\end{tabular}

\section{CONCLUSION}

The van Genuchten model and Brooks-Corey model was selected as the optimal equation to describe the soil water retention characteristic of Jiefangzha irrigation area soils. PTFs based on the ANN model for estimating soil hydraulic characteristics were derived from basic soil 
properties (particle-size distribution, soil organic matter, and bulk density). Among the four parameters of Eq. (1) and Eq. (2), the saturated water content $(\theta$ s) was best predicted through the entire soil data set, while prediction of the value of $n$ and residual water content $(\theta$ r) was the poorest, The developed ANN models for estimating $\theta \mathrm{s}, \theta \mathrm{r}, \ln (\alpha) \ln (\alpha 1) /$ and $n / \lambda$ were tested for their stability and predictability by the double crossvalidation method. It was found that the signs of the regression coefficients and the determination coefficients were stable. The PTFs obtained from this study appear superior in predicting the soil hydraulic parameters, compared to multi-regression PTFs. The PTFs derived in this study were used to estimate soil water retention curve and has better effects. So, we can determine the spatial distribution of regional soil parameters through this method and PTFS which based on the ANN model.

\section{ACKNOWLEDGEMENTS}

This study was partially supported by the National Natural Science Foundation of China (Project No. 50669005).

\section{REFERENCES}

Arya, L.M., Paris, J.F., A physic empirical model to predict the soil moisture characteristic from particle-size distribution and bulk density data. Soil Science Society of America Journal, 1981, 45:1023-1030.

Baumer, O.M., Predicting unsaturated hydraulic parameters. In: van Genuchten, M.Th., et al. (Ed.), Proceedings of the International Workshop on Indirect Methods for Estimating the Hydraulic Properties of Unsaturated Soils. Riverside, CA, 11 - 13 Oct. University of California, Riverside, CA, 1992, : 341 - 354.

Cornelis, V. M., Ronsyn, J., van Meirvenne, M., Hartmann, R., Evaluation of pedotransfer functions for prediction the soil moisture retention curve. Soil Science Society of America Journal, 2001, 65 (3):638 - 648.

Goncalves, M. C., Pereira, L. S., Leij, F. J., Pedo-transfer functions for estimating unsaturated hydraulic properties of Portuguese soils. European Journal of Soil Science, 1997, 48: 387 400 .

Huang G.H, Zhang R.D, Evaluation of soil water retention curve with the pore-solid fractal model, Geoderma, 2005,127: 52-61

Kern, J. S., Evaluation of soil water retention models based on basic soil physical properties. Soil Science Society of America Journal, 1995, 59:1134 - 1141.

Minasny, B., Mcbratney, A. B., The neuro-m for fitting neural network parametric pedotransfer functions. Soil Sci.Am.J. 2002, 66:352-361.

Rawls, W. J, Gish, T. J., Brakensiek, D. L. Estimating soil water retention from soil physical properties and characteristics. Adv. Soil. Sci. Soc. Am. J. 1991, 16:213-234.

Tyler, S.W., Wheatcraft, S.W., 1990. Fractal processes in soil water relation. Water Resour. Res. 26: 1047-1054. 
Tyler, S.W., Wheatcraft, S.W., 1992. Fractal scaling of soil particle size distributions: analysis and limitations. Soil Sci. Soc. Am. J.56:362-369.

van Genuchten, M.Th., 1980. A closed-form equation for predicting the hydraulic conductivity of unsaturated soils. Soil Sci. Soc. Am. J. 44: 892-898.

Vereeken, H., Diels, J., Van Orshoven, J., et al.(with all author names), Functional evaluation of pedo-transfer function for the estimation of soil hydraulic properties. Soil. Sci. Soc. Am. J. 1992, 56:1371-1378.

Wosten, J.H.M., Pachepsky, Y.A., Rawls, W.J., 2001. Pedo-transfer functions: bridging the gap between available basic soil data and missing soil hydraulic characteristics. J. Hydrol. 251:123-150.

Yang, J. Y., Qu, Z. Y.,The determination and evaluation on soil water retention curve model in Hetao irrigation district. Journal of Arid Land Resources and Environment, 2008, 04:5661 (in Chinese). 